\title{
ANALISIS PRODUKTIVITAS KERJA PEGAWAI BALAI LATIHAN KERJA (BLK) PADANG
}

\author{
LIZA ZULBAHRI \\ Universitas Tamansiswa Padang \\ lizazulbahri@yahoo.com
}

\begin{abstract}
The purpose of this study was to determine the effect of work discipline and communication on work productivity of the Padang Job Training Center (BLK) employees. The research method used is descriptive quantitative. The sampling technique used is saturated sampling, so that from the population there are 59 respondents, the data collection methods used are observation, questionnaires, and literature study. The data analysis technique used is multiple linear regression, $t$ test, $F$ test and coefficient of determination. Based on multiple linear regression analysis, the variables of work discipline and communication on work productivity of the Padang Job Training Center (BLK) employees obtained $Y=6.747+0.931 X 1+0.178 X 2+e$. The results of the $t$-test that were carried out showed that the variables of work discipline and communication had a significant effect on the work productivity of the Padang Job Training Center (BLK) employees. The results of the F test proved that the variables of work discipline and communication had a positive and significant effect simultaneously on the work productivity of the Padang Job Training Center (BLK) employees. This can be proven by the value of Fcount > Ftable or 534,421 > 3.16 and a significant level of 0.000 Alpha $(\alpha) 0.05$ while the coefficient of determination is $94.8 \%$. (BLK) Padang, while the remaining 5.2\% is explained by other variables not examined in this study.

Keywords: Work Discipline, Communication, Work Productivity.
\end{abstract}

Abstrak: Tujuan penelitian ini untuk mengetahui pengaruh disiplin kerja dan komunikasi terhadap produktivitas kerja pegawai Balai Latihan Kerja (BLK) Padang. Metode penelitian yang digunakan adalah kuantitatif deskriptif. Teknik pengambilan sampel yang digunakan adalah Sampling Jenuh, sehingga dari populasi tersebut terdapat sampel sebanyak 59 responden, metode pengumpulan data yang digunakan adalah observasi, kuesioner, dan studi kepustakaan. Teknik analisis data yang digunakan adalah regresi linear berganda, uji t, uji $\mathrm{F}$ dan koefisien determinasi. Berdasarkan analisis regresi linear berganda, variabel disiplin kerja dan komunikasi terhadap produktivitas kerja pegawai Balai Latihan Kerja (BLK) Padang didapatkan $\mathrm{Y}=6,747+0,931 \mathrm{X}_{1}+0,178 \mathrm{X}_{2}+\mathrm{e}$. Hasil uji t yang dilakukan didapatkan bahwa variabel disiplin kerja dan komunikasi berpengaruh signifikan terhadap produktivitas kerja pegawai Balai Latihan Kerja (BLK) Padang. Hasil uji F terbukti bahwa variabel disiplin kerja dan komunikasi berpengaruh positif dan signifikan secara bersamaan terhadap produktivitas kerja pegawai Balai Latihan Kerja (BLK) Padang. Hal ini dapat dibuktikan dengan nilai $\mathrm{F}_{\text {hitung }}$ $>\mathrm{F}_{\text {tabel }}$ atau 534,421 $>3,16$ dan tingkat signifikan 0,000 $\leq$ Alpha $(\alpha) 0,05$ sementara koefisien determinasi didapatkan hasil sebesar 94,8\% pengaruh variabel disiplin kerja dan komunikasi terhadap produktivitas kerja pegawai Balai Latihan Kerja (BLK) Padang, sedangkan sisanya $5,2 \%$ dijelaskan oleh variabel lain yang tidak diteliti dalam penelitian ini.

Kata Kunci: Disiplin Kerja, Komunikasi, Produktivitas Kerja.

\section{A. Pendahuluan}

Keberhasilan suatu organisasi atau instansi pemerintah dipengaruhi oleh faktor sumber daya manusia selaku penggerak dari pekerjaan yang dilakukan. Untuk dapat memiliki sumber daya manusia yang berkualitas dan memiliki hasil kerja yang maksimal, organisasi atau instansi pemerintah harus dapat memberdayakan seluruh sumber daya yang ada secara baik. Dengan cara memiliki disiplin kerja yang baik dan komunikasi yang erat dalam pekerjaan 
antara seluruh anggota organisasi untuk menciptakan hasil kerja yang diharapkan. Pemerintah melalui Kementerian Ketenagakerjaan RI Direktorat Jenderal Pembinaan Pelatihan Produktivitas Balai Latihan Kerja (BLK) Padang berupaya memberikan pelatihan kerja kepada masyarakat yang beralamat di Jalan Sungai Balang, Bandar Buat Lubuk Kilangan Kota Padang. Balai Latihan Kerja merupakan sebuah lembaga pemerintah yang dikelola sebagai tempat pelatihan dan pengembangan kemampuan dan skill bagi para pencari kerja. Sesuai dengan Peraturan Menteri Tenaga Kerja dan Transmigrasi Republik Indonesia Nomor 8 Tahun 2014 Tentang Pedoman Penyelenggaraan Pelatihan Berbasis Kompetensi. Sejalan dengan itu terdapat Peraturan Menteri Ketenagakerjaan RI No. 21 Tahun 2015 tentang Organisasi dan Tata Kerja Unit Pelaksana Teknis Bidang Pelatihan Kerja. Balai Latihan Kerja (BLK) Padang mempunyai visi dan misi untuk mewujudkan tenaga kerja dan masyarakat yang produktif, berdaya saing, mandiri dan sejahtera. Untuk itu diperlukan Sumber Daya Manusia yang profesional dan handal sesuai dengan bidang kerjanya masing-masing.

Salah satu aspek kekuatan Sumber Daya Manusia (SDM) dapat tercermin pada sikap dan perilaku disiplin, sebab disiplin mempunyai dampak yang kuat terhadap suatu organisasi untuk mencapai keberhasilan dalam mengejar tujuan yang direncanakan. Pada dasarnya pembentukan disiplin kerja telah dibuat dan dirancang sedemikian rupa di Balai Latihan Kerja (BLK) Padang, namun pada kenyataannya masih terdapat pegawai yang kurang memiliki kedisiplinan dalam bekerja. Masih ada pegawai yang cendrung mengabaikan tanggung jawab dalam tugasnya seperti mengabaikan peserta pelatihan dengan hanya memberikan modul pembelajaran. Masih terdapat pegawai yang masuk dan keluar jam kerja tidak sesuai dengan aturan yang telah ditetapkan. Kendala komunikasi berdasarkan pengamatan pada Balai Latihan Kerja (BLK) Padang, bahwasanya masih ada pegawai yang kurang memahami tugas yang diberikan oleh pimpinan, sehingga berdampak pada produktivitas kerja yang dihasilkan. Selain itu komunikasi sesama pegawai tidak berjalan dengan baik misalnya tidak ada koordinasi sesama pegawai yang ditugaskan sebagai instruktur pelatihan. Kurangnya keterbukaan pegawai yang masa kerjanya sudah lama untuk memberikan umpan balik komunikasi dan tidak adanya reaksi atas pembicaraan kerja yang dilakukan oleh pegawai baru. Pegawai baru masih belum terbiasa dengan cara kerja dan beban kerja, tentunya sangat butuh masukan dari pegawai yang lama. Maka hal tersebut akan berdampak pada pekerjaan yang akan diselesaikan.

Pada umumnya setiap orang dapat berkomunikasi satu sama lainnya. Karena pada dasarnya manusia tidak hanya makhluk individu tetapi juga makhluk sosial yang mempunyai kebutuhan untuk berkomunikasi dengan sesama. Namun tidak semua orang dapat memahami dan merespon komunikasi tersebut. Apabila komunikasi yang terjadi sesama pegawai tidak baik, maka akan menimbulkan ketidaknyamanan didalam bekerja yang tentunya akan menyebabkan produktivitas kerja pegawai menurun. Sejalan dengan itu, terdapat suatu dampak yang signifikan apabila perilaku disiplin tidak diindahkan dan komunikasi kerja tidak berjalan dengan efektif. Dampak dari keduanya yaitu akan mempengaruhi pada produktivitas kerja pegawai organisasi atau perusahaan tersebut. Produktivitas kerja pada dasarnya yakni kemampuan pekerja, pegawai, atau staf pada perusahaan dalam berproduksi dibandingkan dengan input yang digunakan. Seorang pegawai yang bekerja dalam suatu instansi atau perusahaan dapat dikatakan produktif apabila pegawai tersebut mampu menghasilkan output dengan jangka waktu yang singkat dan sesuai dengan tujuan yang diharapkan oleh organisasi atau perusahaan.

Berdasarkan hasil pengamatan di Balai Latihan Kerja (BLK) Padang, pada intinya program yang diberikan oleh Kementerian Ketenagakerjaan RI dalam hal ini Balai Latihan Kerja (BLK) Padang sebagai penyelenggara pelatihan, bahwasanya produktivitas kerja pegawai yang dilakukan selama ini belum maksimal serta masih banyak hal lain yang harus dibenahi. Kurang terciptanya produktivitas kerja yang tinggi dikarenakan masih kurangnya disiplin kerja dan komunikasi pegawai. Selain itu, kemampuan kerja yang dimiliki pegawai tidak sesuai dengan bidang kerja yang ditempatinya. Semangat kerja pegawai yang cenderung menurun dikarenakan kejenuhan akan rutinitas kerja yang dilakukan. Pada intinya seluruh 
pegawai mempunyai tugas dan tanggung jawab yang berbeda-beda sesuai bidang kerjanya masing-masing.

Menurunnya produktivitas kerja pegawai pada suatu organisasi atau perusahaan berkaitan erat dengan disiplin kerja dan komunikasi. Produktivitas kerja memanfaatan penggunaan sumber daya manusia dalam hal ini pegawai yang secara efektif dan efisien, ketepatan atau keserasian penggunaan metode atau cara kerja dibandingkan dengan alat atau waktu yang tersedia dalam rangka mencapai tujuan dari organisasi atau perusahaan. Berdasarkan hal yang diungkap diatas tampak disiplin kerja dan komunikasi yang terjadi dalam organisasi atau perusahaan dapat mempengaruhi pada produktivitas kerja pegawai. Disiplin kerja cerminan kepatuhan seorang pegawai dalam mentaati peraturan organisasi atau perusahaan. Sementara komunikasi yang baik perlu dijaga agar keselarasan informasi dilingkungan organisasi atau perusahaan bisa meningkatkan produktivitas kerja seorang pegawai dalam meyelesaikan tugasnya.

\section{B. Metodologi Penelitian}

Penelitian ini memakai metode penelitian kuantitatif dengan pendekatan deskriptif dengan populasi seluruh pegawai yang bekerja di Balai Latihan Kerja (BLK) Padang, yaitu sebanyak 59 orang pegawai. Teknik pengambilan sampel menggunakan teknik sampling jenuh yaitu menggunakan seluruh populasi sebagai sampel penelitian, alasan penggunaan sampling jenuh dalam penelitian ini karena jumlah populasi dianggap sedikit yaitu kurang dari 100, sampel dalam penelitian ini adalah semua pegawai Balai Latihan Kerja (BLK) Padang yang berjumlah 59 orang.

Jenis data yang digunakan untuk mendukung penelitian ini adalah Data Kualitatif adalah data yang berupa karakteristik kategori atau ciri-ciri khas suatu objek penelitian dan Data Kuantitatif adalah data yang berupa angka-angka atau bilangan baik utuh maupun tidak utuh. Sumber data yang digunakan untuk mendukung penelitian ini adalah data primer dan data sekunder. Teknik analisis data dalam penelitian ini menggunakan Analisa deskriptif, uji validitas, uji realibilitas, analisis regresi linear berganda, uji t, uji $F$ dan uji koefisien determinasi $\left(\mathrm{R}^{2}\right)$.

\section{Hasil dan Pembahasan \\ 1. Hasil Penelitian \\ Hasil Uji Regresi Linear Berganda}

\section{Coefficients $^{\mathbf{a}}$}

\begin{tabular}{|c|c|c|c|c|c|}
\hline \multirow[b]{2}{*}{ Model } & \multicolumn{2}{|c|}{ Unstandardized Coefficients } & \multirow{2}{*}{$\begin{array}{c}\text { Standardized Coefficients } \\
\text { Beta } \\
\end{array}$} & \multirow[b]{2}{*}{$\mathrm{t}$} & \multirow[b]{2}{*}{ Sig. } \\
\hline & $\mathrm{B}$ & Std. Error & & & \\
\hline $1 \quad$ (Constant) & 6.747 & 2.046 & & 3.297 & .002 \\
\hline Disiplin Kerja & .931 & .067 & .827 & 13.962 & .000 \\
\hline Komunikasi & .178 & .063 & .167 & 2.826 & .007 \\
\hline
\end{tabular}

a. Dependent Variable: Produktivitas_Kerja

Sumber: Data Primer yang diolah, 2021

Berdasarkan hasil penelitian dapat dijelaskan bahwa bentuk model persamaan regresi linear berganda untuk pengaruh disiplin kerja dan komunikasi terhadap produktivitas kerja adalah sebagai berikut: $\mathbf{Y}=\mathbf{6 , 7 4 7}+\mathbf{0 , 9 3 1} \mathrm{X}_{\mathbf{1}}+\mathbf{0 , 1 7 8} \mathrm{X}_{\mathbf{2}}+\mathrm{e}$

Dari persamaan linear diatas, dapat diambil kesimpulan bahwa: 1) Nilai konstanta sebesar 6,747 artinya jika disiplin kerja $\left(\mathrm{X}_{1}\right)$ dan komunikasi $\left(\mathrm{X}_{2}\right)$ atau nilainya adalah 0 , maka produktivitas kerja pegawai pada Balai Latihan Kerja (BLK) Padang sudah ada sebesar 6,747 satuan; 2) Nilai koefisien regresi disiplin kerja $\left(X_{1}\right)$ adalah 0,931 artinya setiap peningkatan 284 Lembaga Penelitian dan Penerbitan Hasil Penelitian Ensiklopedia $\quad$ E-ISSN: 2657-0300 
satu satuan disiplin kerja maka produktivitas kerja pegawai Balai Latihan Kerja (BLK) Padang meningkat sebesar 93,1\%, dengan asumsi bahwa variabel komunikasi dianggap tetap atau tidak mengalami perubahan; 3) Nilai koefisien regresi komunikasi $\left(\mathrm{X}_{2}\right)$ adalah 0,178 artinya setiap peningkatan satu satuan komunikasi maka produktivitas kerja pegawai Balai Latihan Kerja (BLK) Padang meningkat sebesar 17,8\% dengan asumsi bahwa variabel disiplin kerja dianggap tetap atau tidak mengalami perubahan.

\section{Uji Hipotesis}

\section{Hasil Uji t (Parsial)}

Berdasarkan tabel coefficients hasil penelitian yang telah dilakukan, maka dapat dijelaskan bahwa untuk Variabel Disiplin Kerja terhadap Produktivitas Kerja diperoleh nilai $t_{\text {hitung }}>t_{\text {tabel }}$, yaitu 13,962 $>1,672$ dengan nilai signifikan sebesar $0,000 \leq$ Alpha $(\alpha) 0,05$, sehingga dapat disimpulkan bahwa $H_{0}$ ditolak dan $H_{l}$ diterima, artinya variabel disiplin kerja $\left(\mathrm{X}_{1}\right)$ berpengaruh positif dan signifikan terhadap produktivitas kerja $(\mathrm{Y})$ dan untuk Variabel Komunikasi terhadap Produktivitas Kerja diperoleh nilai $t_{\text {hitung }}>t_{\text {tabel }}$, yaitu 2,826 $>1,672$, dengan nilai signifikan Sebesar $0,007 \leq$ Alpha $(\alpha) 0,05$, sehingga dapat disimpulkan bahwa $H_{0}$ ditolak dan $\mathrm{H}_{2}$ diterima, artinya variabel komunikasi $\left(\mathrm{X}_{2}\right)$ berpengaruh positif, signifikan terhadap produktivitas kerja (Y).

\section{Hasil Uji F (Simultan)}

ANOVA $^{\mathrm{a}}$

\begin{tabular}{|ll|l|l|l|l|l|}
\hline \multicolumn{2}{|l|}{ Model } & Sum of Squares & df & Mean Square & F & Sig. \\
\hline 1 & Regression & 4920.891 & 2 & 2460.445 & 534.421 & $.000^{\mathrm{b}}$ \\
& Residual & 257.821 & 56 & 4.604 & & \\
\multicolumn{1}{|c|}{ Total } & 5178.712 & 58 & & & \\
\hline
\end{tabular}

a. Dependent Variable: Produktivitas_Kerja

b. Predictors: (Constant), Komunikasi, Disiplin_Kerja

Sumber: Data Primer yang diolah, 2021

Berdasarkan tabel ANOVA, dapat dilihat pada nilai $\mathrm{F}_{\text {hitung }}>\mathrm{F}_{\text {tabel }}$ atau 534,421 $>3,16$ dan tingkat signifikan $0,000 \leq$ Alpha $(\alpha) 0,05$ maka $H_{0}$ ditolak dan $H_{3}$ diterima sehingga dapat disimpulkan bahwa variabel disiplin kerja $\left(\mathrm{X}_{1}\right)$ dan komunikasi $\left(\mathrm{X}_{2}\right)$ secara bersama-sama berpengaruh positif dan signifikan terhadap produktivitas kerja (Y) pegawai Balai Latihan Kerja (BLK) Padang.

\section{Uji Koefisien Determinasi $\left(\mathbf{R}^{2}\right)$}

\begin{tabular}{|l|r|r|r|r|}
\hline $\begin{array}{l}\text { Mod } \\
\text { el }\end{array}$ & R & \multicolumn{1}{|c|}{ Model Summary } & \\
\hline 1 & R Square & \multicolumn{1}{|c|}{ Adjusted R Square } & Std. Error of the Estimate \\
\hline
\end{tabular}

a. Predictors: (Constant), Komunikasi, Disiplin_Kerja

\section{Sumber: Data Primer yang diolah, 2021}

Berdasarkan tabel Model Summary dapat diketahui bahwa nilai koefisien determinasi terdapat pada nilai Adjusted $R$-Square sebesar 0,948. Hal ini berarti kontribusi variabel bebas disiplin kerja $\left(\mathrm{X}_{1}\right)$ dan komunikasi $\left(\mathrm{X}_{2}\right)$ terhadap variabel terikat produktivitas kerja $(\mathrm{Y})$ sebesar $94,8 \%$, sedangkan sisanya sebesar $5,2 \%$ dijelaskan oleh variabel lain yang tidak dibahas dalam penelitian ini. 


\section{Implikasi Hasil Penelitian}

Disiplin kerja berpengaruh signifikan terhadap produktivitas kerja pegawai Balai Latihan Kerja (BLK) Padang, dengan nilai signifikan $0,000 \leq$ Alpha $(\alpha) 0,05$ dan $t_{\text {hitung }}>t_{\text {tabel }}$ sebesar $13,962>1,672$. Tingkat pencapaian paling tinggi pada variabel disiplin kerja terdapat pada butir instrumen dengan bunyi pernyataan "Saya selalu menggunakan seragam kerja seperti yang telah ditentukan oleh instansi", dengan hasil pencapaian sebesar 84,4\% dikatakan baik sesuai dengan kategori pencapaian responden yang telah ditetapkan. Berdasarkan pernyataan tersebut dapat disimpulkan bahwa ketaatan pegawai dalam memakai seragam kerja yang telah ditetapkan sangat membantu dalam meningkatkan produktivitas kerja, sedangkan tingkat pencapaian responden yang paling rendah terdapat pada butir instrumen "Jarak tempat tinggal ketempat kerja tidak mempengaruhi saya untuk lalai dalam bekerja" dengan hasil pencapaian sebesar $71,5 \%$ dikatakan cukup baik.

Berdasarkan pernyataan tersebut dapat disimpulkan bahwa ada responden yang memiliki lokasi tempat tinggal jauh dari Balai Latihan Kerja (BLK) Padang yang menyebabkan responden sering terlambat dalam bekerja, sehingga produktivitas kerja pegawai tidak maksimal. Dari hasil penelitian tersebut, maka dapat disimpulkan bahwa secara umum disiplin kerja pegawai Balai Latihan Kerja (BLK) Padang berjalan sudah cukup baik, namun masih terdapat instrumen yang harus diperbaiki agar penerapan disiplin kerja benar-benar dapat dijalankan ole seluruh pegawai. Harus ada aturan yang jelas dan mengikat terkait dengan pemberian sanksi pada pegawai yang masih sering melanggar aturan. Disamping itu, agar penerapan aturan benar-benar dapat dijalankan secara baik, maka pelaksanaannya harus bersifat tegas dan konsisten sehingga setiap pegawai dapat mematuhi seluruh peraturan yang berlaku. Dengan begitu, penerapan disiplin kerja yang baik akan memberikan dampak yang lebih signifikan terhadap peningkatan produktivitas kerja pegawai Balai Latihan Kerja (BLK) Padang.

Komunikasi berpengaruh signifikan terhadap produktivitas kerja pegawai Balai Latihan Kerja (BLK) Padang, dengan nilai signifikan sebesar 0,007 $\leq$ Alpha $(\alpha) 0,05$ dan $t_{\text {hitung }}>t_{\text {tabel }}$ sebesar 2,826 >1,672. Tingkat pencapaian responden yang paling tinggi terdapat pada butir instrumen "Saya selalu menjadi pendengar yang baik ketika setiap pendapat yang dipaparkan pimpinan maupun rekan kerja", dengan hasil pencapaian sebesar $88,4 \%$ dikatakan baik sesuai dengan kategori pencapaian responden yang telah ditetapkan. Berdasarkan pernyataan tersebut dapat disimpulkan bahwa responden selalu merespon dan mendengarkan dengan baik ketika pimpinan atau rekan kerja sedang memaparkan pendapatnya, sedangkan tingkat pencapaian responden paling rendah terdapat pada butir instrumen "Saya menghargai pendapat yang disampaikan rekan kerja maupun pimpinan", dengan hasil pencapaian sebesar $71,8 \%$ dikatakan cukup baik. Dari pernyataan tersebut dapat disimpulkan bahwa masih ada responden yang kurang menghargai pendapat yang disampikan oleh pimpinan maupun rekan kerja, sehingga mengakibatkan produktivitas kerja pegawai menurun. Dari hasil penelitian tersebut, maka tentunya akan berdampak buruk bagi keberlangsungan aktivitas Balai Latihan Kerja (BLK) Padang Karena banyaknya pegawai yang tidak menghargai pendapat yang disampaikan pimpinan maupun rekan kerja, hal ini pun tentunya akan menghambat proses kerja, sehingga informasi yang semestinya diterima oleh pegawai tidak didapatkan dengan semestinya.

Variabel produktivitas kerja tingkat capaian responden yang paling tinggi terdapat pada butir instrumen "Saya selalu berusaha untuk memperbaiki mutu kerja dengan sebaik mungkin", dengan hasil pencapaian sebesar $87,8 \%$ dikatakan baik sesuai dengan kategori pencapaian responden yang telah ditetapkan. Dari pernyataan tersebut dapat disimpulkan bahwa perkembangan mutu pegawai sangat diperhatikan di Balai Latihan Kerja (BLK) Padang, yaitu dengan diikutsertakannya semua pegawai untuk mengikuti pelatihan keluar kota dan berbagai acara penting yang diselenggarakan oleh Kementerian Ketenagakerjaan, sehingga membuat pegawai lebih bersemangat dalam bekerja, sedangkan tingkat pencapaian responden yang paling rendah terdapat pada butir instrumen "Pimpinan selalu memberi arahan dengan baik sehingga membuat saya semangat dalam bekerja", dengan hasil pencapaian sebesar 
71,5\% dikatakan cukup baik. Dari pernyataan tersebut dapat disimpulkan bahwa minimnya arahan yang diberikan oleh pimpinan dikarenakan seringnya pimpinan mengikuti dinas luar sehingga menyebabkan kurangnya semangat kerja pegawai. Hal ini tentunya akan berdampak pada menurunnya produktivitas kerja pegawai dalam bekerja. Maka dengan itu perlunya memperhatikan tingkat disiplin kerja dan komunikasi sehingga tercapai produktivitas kerja pegawai yang lebih baik. Implikasi dari produktivitas kerja pegawai Balai Latihan Kerja (BLK) Padang sudah terbilang baik, karena pegawai selalu berusaha untuk memperbaiki mutu kerja yang dimilikinya dan berusaha untuk bekerja lebih baik dari sebelumnya. Namun, kurangnya perhatian yang diberikan oleh pimpinan mengakibatkan pekerjaan yang dilakukan tidak terlaksana dengan baik. Oleh karena itu, perhatian yang diberikan pimpinan sangat mempengaruhi produktivitas kerja yang dihasilkan pegawai.

\section{Penutup}

Dari hasil uji regresi linear berganda diketahui arah hubungan antara variabel bebas, yaitu variabel Disiplin Kerja $\left(X_{1}\right)$ sebesar $93,1 \%$ berpengaruh signifikan dan variabel komunikasi $\left(\mathrm{X}_{2}\right)$ sebesar $17,8 \%$ berpengaruh signifikan secara parsial terhadap variabel terikat yaitu produktivitas kerja pegawai $(\mathrm{Y})$. Dengan bentuk persamaannya $\mathrm{Y}=6,747+0,931 \mathrm{X}_{1}+$ $0,178 \mathrm{X}_{2}+$ e. Untuk uji $\mathrm{t}$ (parsial) yang dilakukan terhadap variabel disiplin kerja $\left(\mathrm{X}_{1}\right)$ didapatkan hasil nilai $t_{\text {hitung }}>t_{\text {tabel }}(13,962>1,672)$ dan nilai signifikan $0,000 \leq$ Alpha $(\alpha) 0,05$, ini berarti variabel disiplin kerja berpengaruh signifikan terhadap produktivitas kerja pegawai Balai Latihan Kerja (BLK) Padang. Sedangkan untuk variabel komunikasi $\left(\mathrm{X}_{2}\right)$ didapat hasil nilai $t_{\text {hitung }}>t_{\text {tabel }}(2,826>1,672)$ dan nilai signifikan $0,007 \leq$ Alpha $(\alpha) 0,05$, ini berarti variabel komunikasi berpengaruh positif dan signifikan terhadap produktivitas kerja pegawai Balai Latihan Kerja (BLK) Padang. Untuk Uji F, yaitu pengujian secara bersamaan (simultan) antara variabel disiplin kerja $\left(\mathrm{X}_{1}\right)$ dan komunikasi $\left(\mathrm{X}_{2}\right)$ terhadap produktivitas kerja $(\mathrm{Y})$, didapat nilai $F_{\text {hitung }}>F_{\text {tabel }} 534,421>3,16$ dan tingkat signifikan 0,000 $\leq$ Alpha $(\alpha) 0,05$ artinya disiplin kerja dan komunikasi berpengaruh positif dan signifikan terhadap produktivitas kerja pegawai Balai Latihan Kerja (BLK) Padang. Sedangkan nilai Adjusted R-Square untuk uji koefisien determinasi didapat hasil sebesar 0,948 yang menunjukkan bahwa produktivitas kerja pegawai dipengaruhi oleh disiplin kerja dan komunikasi sebesar 94,8\%, sementara sisanya sebesar 5,2\% dipengaruhi oleh variabel yang tidak diteliti dalam penelitian ini.

\section{Daftar Pustaka}

Bejo Siswanto. 2013. Manajemen Tenaga Kerja Indonesia, Pendekatan Administratif dan Operasional. Bumi Aksara: Jakarta.

Danang Sunyoto, Barhanudin. 2015. Teori Perilaku Keorganisasian. CAPS (Center of Academic Publishing Service): Yogyakarta.

Devito, Josep A. 2010. Komunikasi Antarmanusia. Edisi Ke-5. Karisma Publishing Group: Tanggerang Selatan.

Effendy, Onong Uchjana. 2013. Dinamika Komunikasi. PT. Remaja Rosdakarya: Bandung.

Ginting, Nurmaidah Br. 2018. Pengaruh Disiplin Kerja Dan Komunikasi Terhadap Kinerja Karyawan Di PT. Sekar Mulia Abadi Medan. Fakultas Ekonomi, Universitas Prima Indonesia. AJIE (Asian Journal of Innovation and Entrepreneurship. Vol. 3 No. 2. e ISSN:2477:0574.

Hasibuan, Malayu. 2010. Manajemen Sumber Daya Manusia. PT. Bumi Aksara: Jakarta.

Hasibuan, Malayu. 2018. Manajemen Sumber Daya Manusia. Edisi Revisi. PT. Bumi Aksara: Jakarta.

Marwansyah. 2016. Manajemen Sumber Daya Manusia. Alfabeta: Bandung.

Mangkunegara, Anwar Prabu. 2013. Manajemen Sumber Daya Manusia Perusahaan. Rosda: Bandung.

Mangkunegara, Anwar Prabu. 2017. Manajemen Sumber Daya Manusia Perusahaan. Rosda: Bandung. 
Notoatmodjo, Soekidjo. 2015. Pengembangan Sumber Daya Manusia. Cetakan Kelima. PT. Rineka Cipta: Jakarta.

Purwanto. 2011. Komunikasi Bisnis. Erlangga: Jakarta.

Peraturan Menteri Tenaga Kerja dan Transmigrasi Republik Indonesia Nomor 8 Tahun 2014 Tentang Pedoman Penyelenggaraan Pelatihan Berbasis Kompetensi.

Peraturan Menteri Ketenagakerjaan RI No. 21 Tahun 2015 Tentang Organisasi dan Tata Kerja Unit Pelaksana Teknis Bidang Pelatihan Kerja.

Rivai et. al. 2015. Manajemen Sumber Daya Manusia Untuk Perusahaan Dari Teori ke Praktek. Edisi Ketiga. PT. Raja Grafindo Persada: Jakarta.

Sutrisno, Edy. 2019. Manajemen Sumber Daya Manusia. Kencana Prenanda Media Group: Jakarta.

Sugiyono. 2016. Metode Penelitian Kuantitatif, Kualitatif dan $R \& D$. Alfabeta: Bandung.

Sugiyono. 2019. Metode Penelitian Kuantitatif, Kualitatif dan $R \& D$. Alfabeta: Bandung.

Sunyoto, Danang. 2015. Konsep Dasar Riset Pemasaran \& Perilaku Konsumen. CAPS: Yogyakarta.

Sumarsan, Thomas. 2013. Sistem Pengendalian Manajemen Konsep, Aplikasi \& Pengukuran Kinerja. Indeks: Jakarta.

Somad, Rismi dan Priansa, Donni Juni. 2014. Manajemen Komunikasi (Mengembangkan Bisnis Berorganisasi Pelanggan). Alfabeta: Bandung.

Suyanto. 2011. Menjadi guru profesional, Strategi Meningkatkan Kualifikasi dan Kualitas Guru di Era Global. Esensi Erlangga Group: Jakarta.

Sedarmayanti. 2011. Kerja dan Produktivitas Kerja. Mondar Maju: Bandung.

Sianturi, Ronda Deli. 2016. Peranan Komunikasi Terhadap Produktivitas Kerja Pegawai STMIK Budi Darma Medan. STMIK Budi Darma Medan. Jurnal Ilmiah INFOTEK, Vol.1 No.1. ISSN.2502-6989.

Umar, Husein. 2011. Metode Penelitian Sumber Daya Manusia. PT. Gramedia Pustaka Utama: Jakarta.

Widjaja. 2010. Komunikasi \& Hubungan Masyarakat. PT. Bumi Aksara: Jakarta.

Widodo, Suparno Eko. 2015. Manajemen Pengembangan Sumber Daya Manusia. Pustaka Pelajar: Yogyakarta.

Yusuf, Burhanuddin. 2016. Manajemen Sumber Daya Manusia Di Lembaga Keuangan Syariah. PT. RajaGrafindo Persada: Jakarta. 